\title{
Phototherapy of Sclerosing Skin Diseases
}

\author{
Kamran Ghoreschi Martin Röcken \\ Department of Dermatology, Ludwig-Maximilians University of Munich, Germany
}

Sclerosing skin diseases such as localized scleroderma or lichen sclerosus frequently result in significant morbidity that requires treatment. Until 10 years ago, no generally effective treatment was available for these diseases. In 1992, extracorporeal photopheresis was suggested as treatment for systemic sclerosis, but further studies are required to confirm this early report [1-3]. Two years later, psoralen + UVA, in PUVA bath photochemotherapy, was proposed as effective and safe treatment for localized scleroderma [4]. Since then, it has been shown that all three modes of photochemotherapy, oral PUVA, cream PUVA and PUVA bath photochemotherapy can improve localized scleroderma, but the PUVA bath seems to be the most efficient mode [5-8]. In addition, phototherapy with UVA1 irradiation may resolve established sclerosis, whether applied as high-dose UVA1 (100-120 J/cm $\left.{ }^{2}\right)$ or at doses around $30 \mathrm{~J} / \mathrm{cm}^{2}$ [8-11]. Due to the nature of phototherapy, placebo-controlled studies cannot be performed. Meta-analysis of the various studies confirms that sclerosis resolves either partially or completely in about $60 \%$ of patients receiving 36 treatments of PUVA bath therapy at slightly suberythematous doses or 36 treatments of UVA1. The mechanisms underlying the therapeutic principle remain enigmatic. Molecular analysis of resolving plaques shows a strong increase in the expression of matrix metalloproteinase mRNA such as collagenases and a reduction of procollagen [12-14]. Furthermore, phototherapy has a strong influence on the functioning of immune cells in the skin [15] suggesting that the therapeutic effect relies on the modulation of collagen synthesis.

Based on the success of phototherapy in the treatment of localized scleroderma and eczema [7], several groups analyzed the role of either UVA1 or photochemotherapy in lichen sclerosus. The data of a manuscript reported on pages 245-248 as well as two case reports and one more extended description show that some patients with lichen sclerosus may improve when receiving either cream PUVA or UVA1 therapy [16-18]. However, the number of patients reported until now is relatively small, and the therapeutic modalities, including the mode of phototherapy and the number of treatments, vary widely. Together, the data suggest that phototherapy may be helpful in at least some patients with lichen sclerosus. Similarly, we found that 30 treatments of PUVA bath photochemotherapy or of UVA1 phototherapy may help in selected patients with extragenital lichen sclerosus, but the results were less convincing than in the treatment of localized scleroderma.

Importantly, while phototherapy is the only treatment helpful in scleroderma, the situation is different in lichen sclerosus. More than $80 \%$ improve significantly when treated with clobetasol propionate cream, and most patients with persistent lesions of lichen sclerosus did receive inadequate treatment with topical corticosteroids $[19,20]$. Therefore, we consider PUVA bath photochemotherapy or medium-dose UVA1 phototherapy as first-line therapy of localized scleroderma and topical steroids as

\section{KARGER \\ Fax + 41613061234 \\ E-Mail karger@karger.ch}

www. karger.com
(C) 2002 S. Karger AG, Basel

$1018-8665 / 02 / 2053-0219 \$ 18.50 / 0$

Accessible online at:

www. karger.com/journals/drm
Kamran Ghoreschi

Department of Dermatology

Ludwig Maximilian University, Munich (Germany)

Tel. +49 8951606205, Fax +49 8951606206

E-Mail Kami.Ghoreschi@lrz.uni-muenchen.de 
first-line therapy of extragenital or genital lichen sclerosus. The same rules apply to the treatment of children [21], especially as localized scleroderma may cause constrictions [5]. The data reported here and earlier [16-18] suggest that selected patients with lichen sclerosus may profit from either cream PUVA or UVA1. Detailed studies are required to characterize these patients more precisely and to define the exact role of phototherapy in the treatment of lichen sclerosus.

\section{References}

1 Rook AH, Freundlich B, Jegasothy BV, Perez MI, Barr WG, Jimenez SA, Rietschel RL, Wintroub B, Kahaleh MB, Varga J, et al: Treatment of systemic sclerosis with extracorporeal photochemotherapy: Results of a multicenter trial. Arch Dermatol 1992;128:337-346.

2 Cribier B, Faradji T, Le Coz C, Oberling F, Grosshans E: Extracorporeal photochemotherapy in systemic sclerosis and severe morphea. Dermatology 1995;191:25-31.

3 Enomoto DN, Mekkes JR, Bossuyt PM, Yong SL, Out TA, Hoekzema R, de Rie MA, Schellekens PT, ten Berge IJ, de Borgie CA, Bos JD: Treatment of patients with systemic sclerosis with extracorporeal photochemotherapy (photopheresis). J Am Acad Dermatol 1999;41: 915-922.

4 Kerscher M, Volkenandt M, Meurer M, Lehmann P, Plewig G, Röcken M: Treatment of localised scleroderma with PUVA bath photochemotherapy. Lancet 1994;343:1233.

5 Scharffetter-Kochanek K, Goldermann R, Lehmann P, Hölzle E, Goerz G: PUVA therapy in disabling pansclerotic morphoea of children. Br J Dermatol 1995;132:830-831.

6 Kerscher M, Meurer M, Sander C, Volkenandt M, Lehmann P, Plewig G, Röcken M: PUVA bath photochemotherapy for localized scleroderma: Evaluation of 17 consecutive patients. Arch Dermatol 1996;132:1280-1282.

7 Lüftl M, Degitz K, Plewig G, Röcken M: Psoralen bath plus UVA therapy: Possibilities and limitations. Arch Dermatol 1997;133:15971603.
8 Grundmann-Kollmann M, Ochsendorf F, Zollner TM, Spieth K, Sachsenberg-Studer E, Kaufmann R, Podda M: PUVA-cream photochemotherapy for the treatment of localized scleroderma. J Am Acad Dermatol 2000;43: 675-678.

9 Kerscher M, Dirschka T, Volkenandt M: Treatment of localised scleroderma by UVA1 phototherapy. Lancet 1995;346:1166.

10 Stege H, Berneburg M, Humke S, Klammer M, Grewe M, Grether-Beck S, Boedeker R, Diepgen T, Dierks K, Goerz G, Ruzicka T, Krutmann J: High-dose UVA1 radiation therapy for localized scleroderma. J Am Acad Dermatol 1997;36:938-944.

11 Kerscher M, Volkenandt M, Gruss C, Reuther T, von Kobyletzki G, Freitag M, Dirschka T, Altmeyer P: Low-dose UVA phototherapy for treatment of localized scleroderma. J Am Acad Dermatol 1998:38:21-26.

12 Scharffetter K, Wlaschek M, Hogg A, Bolsen K, Schothorst A, Goerz G, Krieg T, Plewig G: UVA irradiation induces collagenase in human dermal fibroblasts in vitro and in vivo. Arch Dermatol Res 1991;283:506-511.

13 Gruss C, Reed JA, Altmeyer P, McNutt NS, Kerscher M: Induction of interstitial collagenase (MMP-1) by UVA-1 phototherapy in morphea fibroblasts. Lancet 1997;350:1295-1296.

14 Brinckmann J, Neess CM, Gaber Y, Sobhi H, Notbohm H, Hunzelmann N, Fietzek PP, Muller PK, Risteli J, Gebker R, ScharffetterKochanek K: Different pattern of collagen cross-links in two sclerotic skin diseases: Lipodermatosclerosis and circumscribed scleroderma. J Invest Dermatol 2001;117:269-273.
15 Morita A, Werfel T, Stege H, Ahrens C, Karmann K, Grewe M, Grether-Beck S, Ruzicka T, Kapp A, Klotz LO, Sies H, Krutmann J: Evidence that singlet oxygen-induced human $\mathrm{T}$ helper cell apoptosis is the basic mechanism of ultraviolet-A radiation phototherapy. J Exp Med 1997;186:1763-1768.

16 von Kobyletzki G, Freitag M, Hoffmann K, Altmeyer P, Kerscher M: Balneophotochemotherapy with 8-methoxypsoralen in lichen sclerosis et atrophicus. Hautartz 1997;48:488491.

17 Kreuter A, Jansen T, Stucker M, Herde M, Hoffmann K, Altmeyer P, von Kobyletzki G: Low-dose ultraviolet-A1 phototherapy for lichen sclerosus et atrophicus. Clin Exp Dermatol 2001;26:30-32.

18 Kreuter A, Gambichler T, Avermaete A, Happe M, Bacharach-Buhles M, Hoffmann K, Jansen T, Altmeyer P, von Kobyletzki G: Lowdose ultraviolet A1 phototherapy for extragenital lichen sclerosus: Results of a preliminary study. J Am Acad Dermatol 2002;46:251-255.

19 Dalziel KL, Millard PR, Wojnarowska F: The treatment of vulval lichen sclerosus with a very potent topical steroid (clobetasol propionate $0.05 \%$ ) cream. Br J Dermatol 1991;124:461464.

20 Bornstein J, Heifetz S, Kellner Y, Stolar Z, Abramovici H: Clobetasol dipropionate 0.05\% versus testosterone propionate $2 \%$ topical application for severe vulvar lichen sclerosus. Am J Obstet Gynecol 1998;178:80-84.

21 Garzon MC, Paller AS: Ultrapotent topical corticosteroid treatment of childhood genital lichen sclerosus. Arch Dermatol 1999;135:525528. 